Рекомендована д. мед. наук, профр. О. О. Олещук

УДК 616.5-002:615.262:615.454.122:612.017.1

DOI 10.11603/2312-0967.2016.4.7120

\title{
ВПЛИВ МАЗІ, ЩО МІСТИТЬ СУХИЙ ЕКСТРАКТ КОРЕНЯ СОЛОДКИ, НА ФАГОЦИТАРНУ АКТИВНІСТЬ ГРАНУЛОЦИТАРНИХ НЕЙТРОФІЛІВ КРОВІ В МУРЧАКІВ 3 ЕКСПЕРИМЕНТАЛЬНИМ ДЕРМАТИТОМ
}

\author{
(с) Л. М. Малоштан, Е. З. А. Зегхдані, Л. О. Шакіна \\ Національний фрармацевтичний університет, Харків
}

\begin{abstract}
Резюме: у статті наведено результати вивчення впливу мазі «Алерголік», що містить сухий екстракт кореня солодки, на фрагоцитарну активність гранулоцитарних нейтрофілів крові мурчаків з експериментальним алергічним контактним дерматитом, викликаним 2,4-динітрохлорбензолом. Згідно з отриманими даними, мазь «Алерголік», що застосовувалась в умовах лікувально-профрілактичного режиму, мала виражену імунотропну дію, яка полягала в достовірному зниженні, відносно групи контрольної патології, фрагоцитарної активності гранулоцитарних нейтрофрілів, чого не спостерігали в групі тварин, яких лікували препаратом порівняння «Фладекс».
\end{abstract}

Ключові слова: екстракт кореня солодки, імунотропна активність, алергічний контактний дерматит.

Вступ. Предметом особливої уваги сучасної медицини є широка росповсюдженість та неухильне збільшення частоти алергічно-запальних уражень шкіри. Алергічний контактний дерматит (АКД) - одне 3 найпоширеніших захворювань в дерматологічній практиці, яке, за різними даними, спостерігається у 10-24,5 \% населення земної кулі $[5,15]$ та стрімко зростає в усіх вікових групах в Україні [14].

Вирішення проблеми глобальної поширеності та інтенсивного зростання частоти АКД потребує вдосконалення лікарського забезпечення населення України препаратами для ефективного лікування алергічних захворювань шкіри. На сьогодні у зовнішньому лікуванні алергодерматозів використовують топічні кортикостероїди, селективні інгібітори кальціоневрину, топічні антигістамінні препарати, емолієнти, кератолітичні, кератопластичні, епітелізуючі засоби, традиційні протизапальні засоби [13]. Від зазначених вище топічних етіотропних засобів вигідно відрізняються фрітопрепарати місцевої дії, що мають комплексну фрармакологічну дію, можуть тривало застосовуватися без істотних побічних ефектів, характеризуються відносно низькою вартістю і простотою виробництва [10]. За даними численних експериментальних клінічних досліджень широкий спектр біологічної активності мають препарати з кореня солодки голої [9], які виявляють протизапальну, протиалергічну, імуномодулюючу активність $[1,2]$ і $є$ перспективними для використання при АКД.

Серед зазначених біологічних ефектів екстрактів 3 кореня солодки голої особливий інтерес становить вивчення їх імунотропної активності при АКД, оскільки в сучасній науковій літературі акцент робиться на виявлення саме імунологічних порушень в патогене- зі алергічно-запальних уражень шкіри та їх корекції препаратами з імуномодулюючою активністю [11, 15, 16].

Виходячи з вищесказаного, метою наших досліджень було вивчення впливу мазі «Алерголік», що містить сухий екстракт кореня солодки, на антигеннеспецифічну ланку імунного захисту тварин з експериментальним АКД, викликаним 2,4-динітрохлорбензолом.

Методи дослідження. Дослідження було проведене на 24 мурчаках масою 370-410 г. Дослідних тварин розподіляли на 4 групи по 6 тварин у кожній: I - інтактний контроль, II - позитивний контроль - неліковані тварини з АКД, III -тварини з АКД, яких лікували маззю «Алерголік», IV - група порівняння тварини з АКД, яких лікували препаратом порівняння - маззю «Фладекс».

Дію досліджуваних препаратів вивчали в умовах лікувально-профрілактичного режиму, яке починали 3 першого дня сенсибілізації. Моделювання алергічного контактного дерматиту проводили на мурчаках груп II - IV, яких сенсибілізували за методом П. М. Залкан, Е. А. Ієвлевої [4]. Як алерген використовували 2,4-динітрохлобензол (ДНХБ), який наносили у вигляді 5 \% спиртово-ацетонового розчину по 3 краплі щодня протягом 5 днів на шкіру тварин розміром $2 \times 2$ см з лівого боку, з якого попередньо видалили шерстний покрив. Розв'язувальну дозу розчину ДНХБ наносили на 21-шу добу від початку сенсибілізації на інтактний (правий) бік.

Мазь «Алерголік» розроблена на кафедрі технології ліків НфраУ, як препарат порівняння використовували 2 \% мазь «Фладекс» (ТОВ «Фармацевтична компанія «Здоров'я», м. Харків, Україна).

ISSN 2312-0967. Фармацевтичний часопис. 2016. № 4 
Фармакологічні дослідження біологічно активних речовин

Pharmacological researches of biologically active substances

Для оцінки фрункціонального стану імунної системи при алергічних захворюваннях запропоновано ряд тестів, які дозволяють оцінити стан різних ланок імунітету: гуморального та клітинного імунітету, фракторів неспецифрічної та специфрічної резистентності [11].

На першому етапі оцінки імунного статусу організму важливе значення має визначення стану антигеннеспецифрічних фракторів імунного захисту, які беруть безпосередню участь у всіх фразах імунної відповіді. В умовах нашого експерименту для оцінки активності фракторів неспецифічного імунітету визначали фрагоцитарну активність гранулоцитарних нейтрофрілів в суспензії лейкоцитів, яку отримували з гепаринізованої крові [7]. Для досліджень змішували рівні об'єми лейкоцитарної суспензії і відмитої суспензії пекарських дріжджів. Отримані зразки інкубували 30 і 120 хвилин при $37^{\circ} \mathrm{C}$. Після інкубації готували мазки, які фріксували метиловим спиртом і фрарбували барвником Романовського-Гімза. У препаратах під мікроскопом при збільшенні 1000 в імерсійній системі переглядали не менше 200 клітин і підраховували відсоток клітин, що вступили в фрагоцитоз (фрагоцитарний індекс після 30 і 120 хвилинної інкубації - ФІ 30, ФІ 120); середню кількість клітин дріжджів, що були поглинені одним нейтрофрілом (фагоцитарне число після 30 і 120 хвилинної інкубації - ФЧ 30, ФЧ 120); ідекс завершеності фрагоцитозу як частка від ділення ФЧ 30 на ФЧ 120. Фагоцитарну активність гранулоцитарних нейтрофрілів визначали на 7-му добу після нанесення розв'язувальної дози алергену (27 доба експерименту).

Усі дослідження проводили відповідно до національних «Загальноетичних принципів експериментів на тваринах» (Україна, 2011), які узгоджуються з положеннями «Європейської конвенції про захист хребетних тварин, які використовуються для експериментальних та інших наукових цілей» (Страсбург, 1986) [3]. Статистичну обробку даних здійснювали за допомогою пакета програм Statistica for Windows 6.0. Результати вважали дійсними при $\mathrm{p}<0,05$.

Результати й обговорення. В таблиці 1 наведено результати щодо впливу мазі «Алерголік» на антигеннеспецифічну ланку імунного захисту організму на тлі АКД - фрагоцитарну активність гранулоцитарних нейтрофрілів, яку визначали за фрагоцитарним числом (кількість активних фрагоцитів) та індексом завершеності фрагоцитозу (перетравлююча здатність фрагоцитів), що є найбільш інформативними показниками оцінки активності фрагоцитозу [8].

Як видно з даних, наведених у таблиці 1, на 7-му добу після нанесення розв'язувальної дози алергену (27 доба експерименту) спостерігали достовірне підвищення фрагоцитарної активності гранулоцитарних нейтрофрілів крові. Так, в групі контрольної патології (II) показано достовірне зростання кількості активних нейтрофрілів (фрагоцитарного індексу) та поглинальних властивостей нейтрофілів (фагоцитарного числа) в 1,4 раза відносно групи інтактного контролю (I). Аналогічні зміни досліджуваних показників встановлені в групах тварин, яких лікували маззю «Алерголік» (III) та препаратом порівняння «Фладекс» (IV): зростання ФІ в 1,2 - 1,3 раза, відповідно, та ФЧ в 1,3 раза відносно групи інтактного контроля (I).

Отримані дані щодо підвищення показників ФІ та ФЧ у тварин з досліджуваною патологією (групи II - IV) свідчать про наявність природного імунного захисту, спрямованого на локалізацію алергену та його подальше видалення 3 організму. Разом з тим, зниження показника ФІ в групі тварин, яких лікували препаратом «Алерголік» (група III), було достовірним відносно групи контрольної патології (II) та відповідало скороченню термінів одужання та меншій вираженості запальних процесів шкіри в експериментальних тварин на тлі лікування маззю з екстрактом кореня солодки [6].

Індекс завершеності фрагоцитозу (табл. 1) характеризує перетравлюючу здатність фрагоцитів (завершеність фрагоцитозу), при відсутності якої фрагоцитоз порушується та має назву незавершеного. У всіх досліджуваних групах перетравлююча здатність фрагоцитів була збереженою (ІЗФ > 1), що характеризує адекватну імунну відповідь на тлі АКД у всіх досліджуваних групах. Однак слід зазначити, що ІЗФ в групі контрольної патології (II) був достовірно нижчим, а в групах III, IV, які знаходились в умовах профілактично-лікувального режиму, не відрізнявся від групи інтактного контролю (I).

Таблиця 1. Фагоцитарна активність гранулоцитарних нейтрофрілів крові в мурчаків при алергічному контактному дерматиті $\left(\mathrm{X} \pm \mathrm{S}_{\mathrm{x}}, \mathrm{n}=6\right)$

\begin{tabular}{|l|c|c|c|c|}
\hline Показники & $\begin{array}{c}\text { Інтактні тварини } \\
(\mathrm{I})\end{array}$ & $\begin{array}{c}\text { Дерматит без } \\
\text { лікування (II) }\end{array}$ & $\begin{array}{c}\text { Дерматит + мазь } \\
\text { «Алерголік» (III) }\end{array}$ & $\begin{array}{c}\text { Дерматит + мазь } \\
\text { «Фладекс» (IV) }\end{array}$ \\
\hline ФІ 30, \% & $65,17 \pm 1,94$ & $91,17 \pm 2,96^{*}$ & $80,67 \pm 1,71^{*+}$ & $86,67 \pm 3,59^{\star}$ \\
\hline ФЧ 30, ед & $3,06 \pm 0,24$ & $4,28 \pm 0,33^{*}$ & $3,91 \pm 0,30$ * & $4,12 \pm 0,32^{\star}$ \\
\hline ІЗФ = ФЧ 30/ФЧ 120 & $1,41 \pm 0,10$ & $1,09 \pm 0,06^{*}$ & $1,52 \pm 0,11$ & $1,27 \pm 0,09$ \\
\hline
\end{tabular}

Примітки: $\mathrm{n}$ - кількість тварин у кожній групі;

* - відмінності, значущі відносно інтактної групи (I), p<0,05;

+ - відмінності, значущі відносно групи патології (II), p<0,05;

\# - відмінності групи III, значущі відносно групи порівняння (IV), p<0,05.

ISSN 2312-0967. Pharmaceutical review. 2016. № 4 
Фармакологічні дослідження біологічно активних речовин

Pharmacological researches of biologically active substances

Таким чином, на основі проведеного доклінічного дослідження на моделі АКД в мурчаків було показано, що мазь «Алерголік» із сухим екстрактом кореня солодки має виражену імунотропну активність стосовно фрункціональної активності гранулоцитарних нейтрофілів. Згідно з результатами роботи [12], нормалізація функціанальної активності нейтрофрільних лейкоцитів за рахунок імуномодуляторів в комплексній терапії алергодерматозів дозволяє швидше купірувати загострення шкірних проявів алергії, скоротити терміни лікування, попередити рецидивування і збільшити тривалість ремісії хвороби. Цей фракт свідчить про перспективність подальшого вивчення мазі «Алерголік» із сухим екстрактом кореня солодки 3 метою її використання в терапії алергодерматозів.

Висновки. 1. На моделі алергічного контактного дерматиту в мурчаків досліджувана мазь «Алерголік» мала виражену імунотропну активність, яка полягала в достовірному зниженні фрагоцитарної активності нейтросрілів відносно групи контрольної патології, чого не спостерігали в групі тварин, яких лікували препаратом порівняння «Фладекс».

Отримані результати свідчать про перспективність подальшого вивчення мазі «Алерголік» із сухим екстрактом кореня солодки з метою її використання в терапії алергодерматозів.

\section{Список літератури}

1. Актуальные проблемы биологии, химии и медицины : монограсрия / [Ю. П. Зарубин, П. П. Пурыгин, Т. А. Соколова-Попова и др.]. - Одесса : КУПРИЕНКО CB, 2014. - 235 c.

2. Аммосов А. С. Солодка - технология, препараты, применение В мировой практике: краткий обзор патентных источников / А. С. Аммосов, В. И. Литвиненко // Фармаком. - 2003. - № 4. - C.1-8.

3. Біотична експертиза доклінічних та інших наукових досліджень, що виконуються на тваринах: метод. рекомендації / О. Г. Резніков, А. І. Соловйов, Н. В. Добреля [та ін.] // Вісник фрармакології та фрармації. -2006 . - № 7. - С. 47-61.

4. Залкан П. М. Влияние синтетических моющих средств на реактивность кожи морских свинок / П. М. Залкан, Е. А. Иевлева // Актуальные вопросы профессиональной дерматологии. - Москва. - 1965.

- C. 106-112.

5. Землякова С. С. Аллергический контактныйдерматит и ассоциированные аллергодерматозы: клиникоэпидемиологический анализ и иммунологические характеристики, особенности терапии и профилактики: дис. ... кандидата мед. наук : 14.01.10 / Землякова Светлана Сергеевна. - Москва, 2010. - 180 с.

6. Изучение фрармакологической активности мази «Аллерголик» на модели контактного аллергического дерматита / Е. Ю. Яценко, Л. Н. Малоштан, Эсам Зургани А. Зегхдани [и др.] // Фармация Казахстана. 2016. - № 2. - С. 16-19.

7. Камышников В. С. Справочник по клиникобиохимическим исследованиям и лабораторной диагностике / В. С. Камышников. - М. : МЕДпрессинфрорм, 2004. - 920 с.

8. Кишкун А. А. Руководство по лабораторным методам диагностики / А. А. Кишкун. - М. : ГЄОТАР-Медиа, 2007. $-800 \mathrm{c}$.

9. Компендиум 2014 - лекарственные препараты / под ред. В. Н. Коваленко. - К. : МОРИОН, 2014. - С. 1593.

10. Куркин В. А. Основы фритотерапии: учебное пособие [для студентов фрармацевтических вузов] / В. А. Куркин. - Самара : «СамГМУ Росздрава»; ГОУ ВПО «СамГМУ Росздрава». - 2009. - 963 с

11. Локальный и системный иммунный ответ у больных тяжелыми атопическими дерматитами / Д. Д. Ниязов, Т. М. Филимонова, О. Г. Слисютина [и др.] // Российский аллергологический журнал. - 2011. - № 5. - С. 24-29.

12. Мельник В. А. Состояние функций полиморфноядерных нейтрофилов при атопических дерматитах у детей / В. А. Мельник, Л. И. Слюсарь, Е.И.Беседина // Аллергические заболевания у детей: современные проблемы диагностики, терапии и реабилитации: научно-практическая конференция, декабрь 1998 г. : тез. докл. - Новосибирск, 1998. - С. 23-30.

13. Резніченко Н. Ю. Алергічний контактний дерматит: сучасні уявлення про лікування на основі огляду наукової літератури / Н. Ю. Резніченко // Актуальні питання фрармацевтичної і медичної науки та практики. - 2013. - № 3. - C. 69-72.

14. Соціальна медицина та організація охорони здоров'я: підруч. [для студ. вищ. навч. закл.] / [ Ю. В. Вороненко, О П. Гульчій, С. М. Зоріна та ін.]; під ред. Ю. В. Вороненко, В. Ф. Москаленко. - Тернопіль : Укрмедкнига, 2000. - 676 с.

15. Allergic contact dermatitis: Immune system involvement and distinctive clinical cases / S. Imbesi, P. L. Minciullo, S. Isola [et all.] // Allergologia et Immunologia. - 2011. V. 39, № 6. - P.374-377

16. Enzymatic homeostasis in peripheral blood lymphocytes in rats with dermatitis / A. I. Bereznyakova, V. F. Cheremisina, M. Mrozkowiak [et al.] // Journal of Education, Health and Sport. -2015. - Vol. 5, №11. - P. 203-216. 
Фармакологічні дослідження біологічно активних речовин

Pharmacological researches of biologically active substances

\title{
ВЛИЯНИЕ МАЗИ, СОДЕРЖАЩЕЙ СУХОЙ ЭКСТРАКТ КОРНЯ СОЛОДКИ, НА ФАГОЦИТАРНУЮ АКТИВНОСТЬ ГРАНУЛОЦИТАРНЫХ НЕЙТРОФИЛОВ КРОВИ У МОРСКИХ СВИНОК С ЭКСПЕРИМЕНТАЛЬНЫМ ДЕРМАТИТОМ
}

\author{
Л. Н. Малоштан, Е. З. А. Зегхдани, Л. А. Шакина \\ Национальный фрармацевтический университет, Харьков
}

Резюме: в статье приведены результаты исследования влияния мази «Аллерголик», содержащей сухой экстракт корня солодки, на фрагоцитарную активность гранулоцитарных нейтрофилов крови морских свинок с экспериментальным аллергическим контактным дерматитом, вызванным 2,4 -динитрохлорбензолом. Согласно полученным данным, мазь «Аллерголик», которая применялась в условиях лечебно-профилактического режима, имела выраженное иммунотропное действие, что проявлялось в достоверном снижении относительно группы контрольной патологии фрагоцитарной активности гранулоцитарных нейтрофилов, чего не наблюдали в группе животных, которых лечили препаратом сравнения «Фладекс».

Ключевые слова: экстракт корня солодки, иммунотропная активность, аллергический контактный дерматит.

\section{INFLUENCE OF THE OINTMENT, WHICH CONTAINS THE DRY EXTRACT OF LICORICE RHIZOME, ON THE PHAGOCYTIC ACTIVITY OF BLOOD NEUTROPHIL GRANULOCYTES IN GUINEA PIGS WITH EXPERIMENTAL DERMATITIS}

\section{M. Maloshtan, E. A. Z. Zeghdani, L. A. Shakina}

National University of Pharmacy, Kharkiv

Summary: the influence of the ointment «Allerholik», which contain the dry extract of licorice rhizome, on the phagocytic activity of blood neutrophil granulocytes in Guinea pigs was investigated on the model of the experimental allergic contact dermatitis caused by 2.4-dinitrochlorobenzene. According to the data obtained, the ointment «Allerholik», which was used in preventive and therapeutic treatments, had a pronounced immunotropic effect compared with untreated animals significant decrease of phagocytic activity of neutrophils was shown, which wasn't observed in the group of animals treated by the reference drug - ointment «Fladeks».

Key words: extract of licorice rhizome, immunotropic activity, allergic contact dermatitis. 